\title{
Basophils as Key Regulators of Allergic Inflammation and Th2-type Immunity
}

\author{
Bernhard F. Gibbs
}

\begin{abstract}
Basophils have long been suspected as playing more than a bystander role in initiating and maintaining allergic disorders, despite their relatively low numbers compared with other effector cells, such as mast cells and eosinophils. In vitro studies clearly demonstrated their propensity to generate proallergic cytokines, such as interleukin 4 and interleukin 13, as well as histamine and leukotrienes after simulation with allergens and innate IgE-dependent triggers. However, only very recently have mouse basophils been identified as key regulators of allergy in vivo, including orchestrating Th2 immunity to protease allergens in the induction phase. This review highlights these exciting advances that go far in unraveling our understanding of basophil function in the orchestration of allergic inflammation.
\end{abstract}

Key Words: basophils, mast cells, Th2 immunity, allergy

(WAO Journal 2008;123-128)

$\mathrm{C}^{\circ}$ ompared with other allergic effector cells, basophils are relatively rare and constitute only $1 \%$ or less of circulating leukocytes. Like their tissue-fixed mast cell counterparts, basophils express high-affinity immunoglobulin E (IgE) receptors (FceRI), secrete histamine and eicosanoids (primarily $\mathrm{LTC}_{4}$ ) after IgE-mediated provocation, and undergo metachromatic staining. However, before the emergence of basophil-specific markers, it was hard to demonstrate their presence in organs affected by allergic inflammation. Despite this, in the early 1990s, indirect evidence pointed to their presence in these tissues during late-phase reactions based on their ability to release histamine without concomitant prostaglandin $\mathrm{D}_{2}\left(\mathrm{PGD}_{2}\right)$ or mast cell tryptase. ${ }^{1,2}$ These observations increased interest in basophils as allergic effector cells, but during this period, few could have foreseen the crucial functions of these cells in actually orchestrating allergic inflammatory events, let alone possibly helper $\mathrm{T}$ cell type 2 (Th2) immunity itself.

A major turning point that changed our perceptions of allergic effector cells per se was the discovery that mast cells produce a variety of inflammatory and immunomodulatory cytokines. Murine mast cells or tumorigenic mast cell lines, in particular, were found to generate interleukin 1 (IL-1), IL-3, IL-4, IL-5, IL-6, IL-8, IL-13, granulocyte macrophage colonystimulating factor, and tumor necrosis factor- $\alpha$ (TNF- $\alpha$ )

Received for publication February 5, 2008; accepted April 3, 2008.

From the Medway School of Pharmacy, University of Kent, Kent, United Kingdom.

Reprints: Bernhard F. Gibbs, Medway School of Pharmacy, University of Kent, Central Ave, Chatham Maritime, Kent, ME4 4TB, United Kingdom. E-mail: B.F.Gibbs@kent.ac.uk

Copyright (C) 2008 by World Allergy Organization besides several others after IgE-dependent activation ${ }^{3}$ (reviewed in Gordon et $\mathrm{al}^{4}$ ). It was shown that mast cells could potentially drive developing helper $\mathrm{T}$ cell responses as well as up-regulate adhesion molecules on endothelial cells responsible for attracting other allergic inflammatory cells. ${ }^{5-7}$ However, unlike rodent mast cells, the ability of primary human mast cells from either the lung or skin to generate Th2type cytokines (especially IL-4) seems to be rather limited. ${ }^{8-11}$ In contrast, human basophils rapidly synthesize and release IL- $4,{ }^{12-15}$ in some cases even from preformed stores, ${ }^{15}$ and IL$13,{ }^{15-17}$ cytokines that play a crucial role in supporting underlying atopy.

Although human basophils share certain characteristics with their mast cell counterparts, they differ in a number of important aspects regarding their ability to react to various stimuli and the types of mediators they release (Fig. 1). In terms of cytokine synthesis, human basophils are relatively constrained to generating IL-4 and IL-13 rather than IL-5 or the multitude of proinflammatory cytokines ascribed to mast cells. ${ }^{18}$ This sets the scene for the emergence of the basophil as a potential supporter of Th2 responses, evidence of which is highlighted in this review.

\section{BASOPHILS ARE MAJOR SOURCES OF IL-4 AND IL-13 AND ARE RECRUITED TO TISSUES AFFECTED BY ALLERGIC INFLAMMATION}

Basophils express a wide variety of chemokine receptors (eg, CCR1-3, CXCR1, CXCR3, and CXCR4) and also respond to a range of chemokines and cytokines that facilitate their migration. ${ }^{19,20}$ In recent years, the basophil-specific BB1 and 2D7 antibodies have been used with great success to demonstrate the presence of basophils in various tissues affected by allergic disease, such as the lung, skin, and nose (reviewed in Falcone et $\mathrm{al}^{21}$ ). During allergen-induced asthmatic reactions, basophils were shown to be responsible for $72 \%$ of IL-4 protein in the bronchial mucosa, ${ }^{22}$ an observation that also correlates to murine asthma models. ${ }^{23} \mathrm{In}$ another study, Devouassoux and coworkers ${ }^{24}$ demonstrated that the early production of IL-4 and IL-13 in the peripheral blood of asthmatic patients after allergen challenge was exclusively basophil derived. A real-time quantitative polymerase chain reaction-based assay in whole blood also identifies basophils as the most prominent source of IL-4 and IL-13 after stimulation with the cat allergen Fel d1. ${ }^{25}$ These findings verified the earlier in vitro investigations (described previously) showing that basophils are geared to rapid generation of these cytokines.

Interleukin 4 and IL-13 are archetypal proallergic cytokines. They increase vascular cell adhesion molecule-1 


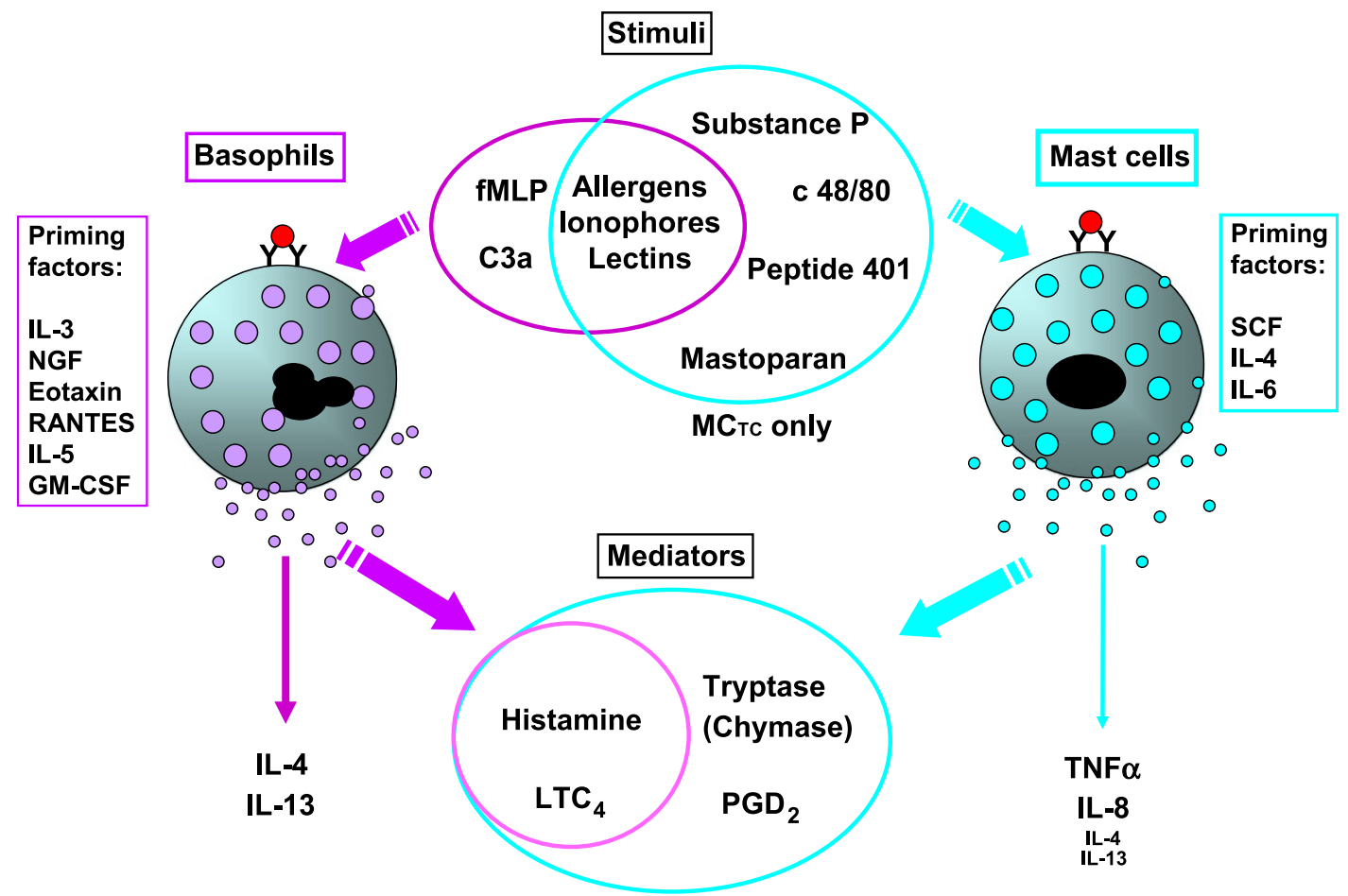

FIGURE 1. Summary of human mast cell and basophil heterogeneity to stimulation and mediator generation (for better clarity, this is not a comprehensive list). Although both cell types react to lgE-mediated triggers, ionophores, basophils are more reactive to fMLP and C3a than most human mast cell types. Conversely, connective tissue mast cells $\left(\mathrm{MC}_{\mathrm{TC}}\right)$, but not mucosal mast cells (MC $\left.\mathrm{C}_{\mathrm{T}}\right)$ or basophils, are stimulated by neuropeptides and polybasic amines. In terms of mediator secretion, both cells secrete histamine and LTC 4 . Mast cells additionally release tryptase as well as, in the case of $\mathrm{MC}_{\mathrm{TC}}$, chymase and PGs (primarily $\mathrm{PGD}_{2}$ ). Human basophils and mast cells differ in terms of cytokine synthesis: basophils are more restricted to IL-4 and IL-13 generation, whereas isolated mast cells produce TNF-a and IL-8 in vitro, although this may not reflect in vivo settings. Basophils are also known to respond to a large number of growth factors and chemokines that dramatically enhance their ability to generate mediators after lgE-dependent triggering. Human mast cells, on the other hand, are generally only responsive to priming by stem cell factor (SCF) and, to some extent, by IL-4 and IL-6. GM-CSF indicates granulocyte macrophage colony-stimulating factor; RANTES, regulated on activation normally T-cell expressed and secreted.

expression on the microvascular endothelium and eotaxin synthesis from airway epithelial cells, supporting leukocyte influx into affected tissues during late-phase responses. ${ }^{26-28}$ They also play a key role in B-cell immunoglobulin class switching to favor IgE synthesis, and IL-4 is a vital factor for the early differentiation of $\mathrm{CD}^{+}$lymphocytes to a Th2 type (reviewed in Haas et $\mathrm{al}^{29}$ ).

Given that basophils are major producers of these cytokines, an immunomodulatory role in supporting the previously mentioned events by these cells seems highly plausible (Fig. 2). However, direct in vivo evidence for this has been, until very recently, scarce, owing largely to a lack of basophil knockout animal models because a basophilspecific growth factor has not yet been identified. Although growth factors such as IL-3, in particular, promote basophil development from CD $34^{+}$progenitors (and controversially, murine mast cells, but not human mast cells), basophils are still present in IL-3-deficient mice. ${ }^{30}$ This has stifled the development of basophil-knockout models analogous to mast cell-deficient mice (lacking c-kit receptors or c-kit ligand/stem cell factor, mandatory for mast cell maturation). To circumvent this problem, basophil-specific monoclonal antibodies have been used to deplete circulating murine basophils, ${ }^{31}$ a technique that could potentially revolutionize future investigations into unraveling their biological roles.

\section{BASOPHILS REGULATE LATE-PHASE REACTIONS AND CHRONIC ALLERGIC INFLAMMATION}

Although murine mast cells can readily produce the Th2type cytokines ascribed to human basophils, implying a redundancy in function for the latter, it is remarkable that some of the strongest evidence for a major role of basophils in allergic inflammation comes from murine allergy models. One such model uses transgenic mice generating 2,4,6-trinitrophenol (TNP)-specific IgE that gives rise to a variety of allergic responses after subcutaneous TNP injection. ${ }^{32}$ This consists of early- and late-phase allergic responses, chronic allergic inflammation, and anaphylaxis after intravenous TNP injection. It was demonstrated that these mice fail to display signs of chronic allergic inflammation after prior depletion of circulating basophils. ${ }^{31}$ Furthermore, a combinational approach, using a range of mice genetically defective in various lymphocytes and mast cells and reconstitution experiments, showed that mast cells, $\mathrm{T}$ cells, and natural 


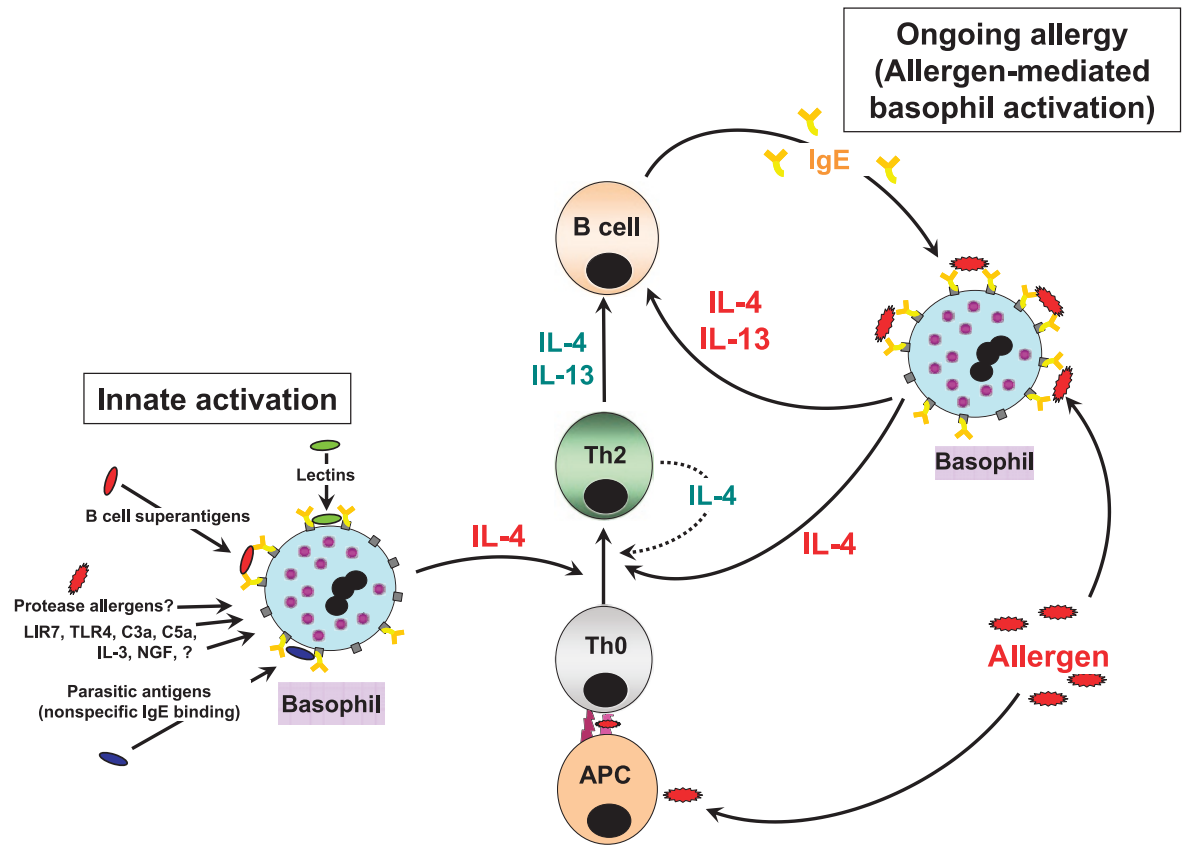

FIGURE 2. Simplified overview of the immunomodulatory roles of basophils. APC indicates antigen-presenting cells.

killer cells (NK) and natural killer T cells (NKT) were not necessary for the late-phase allergic reactions, in stark contrast to basophils. $^{33}$

\section{BASOPHILS AS POTENTIAL MODULATORS OF LOCAL IgE SYNTHESIS}

Recently, it has been shown that $\mathrm{B}$ cells residing in the bronchial mucosa of asthmatic patients undergo class switching to IgE synthesis, supporting earlier observations regarding their local generation of allergen-specific $\operatorname{IgE}$ in the nasal mucosa. ${ }^{34}$ Gould et $\mathrm{al}^{35}$ calculated that this local IgE production may account for a substantial portion of IgE saturating allergic effector cells within these sites. The fact that IgE synthesis occurs not only in the lymph nodes but locally within organs affected by allergic inflammation permits immunomodulatory input from resident allergic effector cells such as basophils.

Immunoglobulin E class switching is controlled by IL-4, IL-13, and CD40 ligand (CD40L) binding to its counterpart receptor on $\mathrm{B}$ cells. Yanagihara et $\mathrm{al}^{36}$ showed that basophils can indeed direct polyclonal IgE synthesis in vitro by virtue of their ability to produce the previously mentioned stimuli, the effects of which were inhibited by the addition of neutralizing antibodies against IL-4, IL-13, and CD40L. In sharp contrast, cord blood-derived human mast cells failed to elicit this response. This is in agreement with an earlier study showing that although basophils (either primary or KU812 cell lines) and human mast cells (HMC-1) expressed CD40L, mast cells could only stimulate B-cell IgE synthesis in the presence of exogenously applied IL-4. ${ }^{37}$ Although these observations have yet to be fully verified by in vivo investigations, the liaison between tissue-associated basophils and B cells certainly represents a plausible circulus vitiosus of increasing $\mathrm{IgE}$ and effector cell sensitization central to the pathophysiology of allergic disease.

\section{DO BASOPHILS CONTROL Th2 IMMUNITY?}

As already discussed, it is increasingly clear that basophils are the main early source of IL-4 after allergen exposure in peripheral blood and asthmatic airways. Unlike IL-13, IL-4 is unique in driving $\mathrm{CD}^{+} \mathrm{T}$ cells to a Th2 phenotype, which subsequently produce IL-4, IL-13, and other Th2-type cytokines themselves (reviewed in Haas et $\mathrm{al}^{29}$ ). The importance of IL-4 in initiating Th2 development was confirmed by studies showing that mice lacking either IL$4 \mathrm{R} \alpha$ or Stat6 (which controls IL-4-directed signaling) do not generate Th2 immune responses. ${ }^{38,39}$ In addition to governing chronic allergic inflammation and perhaps also $\operatorname{IgE}$ synthesis, basophil-derived IL-4 may thus play a role in controlling Th2 immunity too. At the very least, basophils may exacerbate existing Th2 polarization in ongoing allergic disease. Further evidence for an association between basophils and Th2 lymphocytes is given by clinical studies showing that specific allergen immunotherapy reduces basophil reactivity and numbers as well as Th2 immunity. ${ }^{40}$

Although there is strong evidence to show that basophils are capable of supporting local Th2 immune responses at sites of allergic inflammation and possibly regulating local B-cell IgE class switching, several important issues remain. First, do basophils migrate to the lymph nodes, which are the prime tissue sites for developing immune responses? Second, do basophils participate in the induction phase of Th2 immunity? The latter would require basophils to be activated by mechanisms that do not require the presence of surfacebound antigen-specific $\operatorname{IgE}$. 
Basophils are not usually attributed to being present in the lymph nodes. However, a recent study has clearly demonstrated that they transiently migrate into the draining lymph nodes of mice after immunization with the protease allergen, papain. ${ }^{41}$ Interestingly, these investigations also showed that basophils were activated by protease allergen by innate triggering and released $\mathrm{Th} 2$ cytokines that were essential for initiating Th2 differentiation. A considerable proportion of activated basophils within the lymph nodes also released thymic stromal lymphopoietin (TSLP), in addition to IL-4, and were the only cell type within the lymph nodes that produced this Th2-driving factor. The TSLP-neutralizing antibodies indeed diminished Th2 differentiation without affecting either dendritic cell maturation and migration or basophil accumulation within the draining lymph nodes. This report clearly suggests that mouse basophils play a vital role in innate immune recognition leading to $\mathrm{Th} 2$ responses by secreting IL-4 and TSLP.

Although the previously mentioned data add further credence to the immunomodulatory capabilities of basophils, there are a number of unresolved issues. For example, TSLP production in human basophils has not yet been reported, and there is contradictory evidence regarding their ability to react to specific protease-activated receptor agonists ${ }^{42}$ versus protease allergens (eg, Der p1). ${ }^{43}$ Elucidating the mechanisms of basophil migration into the lymph nodes after protease allergen challenge and whether this migration takes place in other settings also need addressing. For instance, although basophils have been shown to be critical in recruiting Th2 cells into affected tissues after Nippostrongylus brasiliensis infection (which also causes a substantial Th2-type response), ${ }^{44}$ their innate activation was not necessary for Th2 differentiation in the lymph nodes. ${ }^{45}$ Thus, although the evidence for basophil-directed immunomodulation within organs such as the lung is strong, their ability to control Th2 immunity, as well as IgE class switching, within lymphatic tissues is by no means fully resolved. This applies both to their ability to participate in early (innate) events of conditioning Th2 responses and to ongoing allergic disease, where their role in the lymphatic tissues is also not known.

\section{INNATE ACTIVATORS OF BASOPHIL CYTOKINE SYNTHESIS}

There is now a wealth of literature showing that human basophils produce IL-4 and IL-13 in nonsensitized individuals by various innate triggers, some of which cause activation of Fce RI by binding to $\operatorname{IgE}$ in a non-antigen-specific manner (reviewed in Falcone et $\mathrm{al}^{21,46}$ ). These include parasitic antigens (eg, Schistosoma mansoni, Echinococcus multilocularis), lectins (eg, concanavalin A), and viral superantigens (eg, human immunodeficiency virus $1 \mathrm{gp} 120$ ) that activate basophils by binding to non-antigen-specific IgE antibodies. Furthermore, basophil cytokine release is also caused by engagement of certain leukocyte immunoglobulinlike receptors (eg, LIR7), toll-like receptors (eg, TLR2), and to a more limited extent, by $\mathrm{C} 5 \mathrm{a} / \mathrm{C} 3 \mathrm{a}$ and formyl-methionyl-leucyl-phenylalanine (fMLP).

In addition to the previously mentioned innate stimuli, basophil growth factors such as IL-3 and nerve growth factor
(NGF) can also induce considerable levels of Th2-type cytokine synthesis. ${ }^{47,48}$ Although this usually occurs only at relatively high concentrations of either IL-3 or NGF (above 10 $\mathrm{ng} / \mathrm{mL})$, lower amounts $(1 \mathrm{ng} / \mathrm{mL})$ substantially enhance $\mathrm{IgE}$ dependent basophil mediator release to both specific allergens and innate activators. Regarding NGF, there is compelling evidence to suggest that this neurotrophin participates in both animal models of allergy and in human allergic asthma, where it correlates with disease severity and IgE levels. ${ }^{49,50}$ Because basophils from asthmatic donors display a hyperreleaser phenotype, ${ }^{51}$ factors such as NGF may have an important function in enhancing the synthesis of basophil-derived Th2type cytokines and thereby their proallergic immunomodulatory roles (Fig. 2).

\section{BASOPHILS AS TARGETS FOR ANTIALLERGIC THERAPY}

Given their potential in supporting both allergic inflammation and underlying Th2 immunity, basophils are an attractive target for antiallergic therapy. Their abilities to release mediators are inhibited by certain existing antiallergic agents such as glucocorticoids, methylxanthines, and calcineurin inhibitors, and this may partially explain their clinical effectiveness. Other traditional therapeutic agents, such as cromoglycate, have no known effects on basophils and highly variable actions on various mast cell subtypes.

The well-known limitations of these agents, including their heterogeneous actions on basophils and mast cells, have prompted renewed attempts to block allergen-mediated Fc $\in$ RI activation of these cells. One promising approach is to prevent free IgE antibodies from binding to FceRI using monoclonal anti-IgE (omalizumab), which reduces both effector cell sensitization and FceRI expressions. Treatment with omalizumab in allergic rhinitis patients has been shown to strikingly reduce basophil reactivity and lead to a rapid decline in FceRI expression, which was faster in comparison to mast cells. ${ }^{52}$ In parallel, these authors also observed a reduction in allergeninduced wheal size. A similar decline in basophil reactivity after omalizumab therapy is seen in allergic asthma, although in these settings, this was not always matched by clinical improvement. ${ }^{53}$

Basophils may also be directly affected by rush desensitization regimens, which has been ascribed to a loss of Syk expression, ${ }^{54}$ a crucial stimulatory signal associated with FceRI activation. But their signal transduction machinery additionally encompasses a range of inhibitory signals that may contribute to their functional desensitization. One such signaling target is the src homology 2 domain-containing inositol 5ôphosphatase (SHIP), an inhibitory enzyme that is centrally involved in IgE-mediated signaling in both basophils and mast cells. ${ }^{55-57}$ The SHIP has been shown to be mobilized upon the activation of inhibitory receptors, such as IRp60 (CD300a), leading to a dramatic reduction in allergic effector cell function. ${ }^{58}$ CD 300a, CD200R, ${ }^{59}$ Siglec- $8,{ }^{60}$ and FcyRIIb (the latter only blocks basophil responses in conjunction with FceRI co-cross-linking ${ }^{61}$ ) up-regulate SHIP expressions and may in the future be exploited for antiallergic therapies. 


\section{CONCLUSIONS}

Recent in vivo investigations have provided exciting new inroads that support earlier in vitro studies showing that basophils are far from mere bystander cells of allergy and Th2 immunity. Their propensity to rapidly deliver Th2 cytokines under a variety of conditions and their necessity in eliciting chronic allergic inflammation underlines their immunomodulatory potential. However, the details concerning these actions still need to be elucidated, also in view of input from regulatory $\mathrm{T}$ cells that may down-regulate proallergic responses after parasitic helminth infections. The physiological purpose of basophils also remains elusive, as well as their interactions with other effector cells of the allergic inflammatory response. Nonetheless, there is overwhelming evidence to show that basophils contribute to the symptoms of allergic disease and support underlying Th2 immunity, especially in ongoing allergy. This cell therefore poses an obvious therapeutic target, and identifying ligands for inhibitory receptor engagement may be a promising approach to generate new antiallergic therapies.

\section{REFERENCES}

1. Lichtenstein LM, Bochner BS. The role of basophils in asthma. Ann NY Acad Sci. 1991;629:48-61.

2. Atkins PC, Schwartz LB, Adkinson NF, von Allmen C, Valenzano M, Zweiman B. In vivo antigen induced cutaneous mediator release: simultaneous comparisons of histamine, tryptase, and prostaglandin D2 release and the effect of oral corticosteroid administration. J Allergy Clin Immunol. 1990;86:360-370.

3. Burd PR, Rogers HW, Gordon JR, Martin CA, Jayaraman S, Wilson SD, et al. Interleukin 3-dependent and -independent mast cells stimulated with IgE and antigen express multiple cytokines. J Exp Med. 1989;170:245-257.

4. Gordon JR, Burd PR, Galli SJ. Mast cells as a source of multifunctional cytokines. Immunol Today. 1990;11:458-464.

5. Huels C, Germann T, Goedert S, Hoehn P, Koelsch S, et al. Co-activation of naive $\mathrm{CD} 4+\mathrm{T}$ cells and bone marrow-derived mast cells results in the development of Th2 cells. Int Immunol. 1995;7:525-532.

6. Walsh LJ, Trinchieri G, Waldorf HA, Whitaker D, Murphy GF. Human dermal mast cells contain and release tumor necrosis factor alpha, which induces endothelial leukocyte adhesion molecule. Proc Natl Acad Sci U S A. 1991;88:4220-4224.

7. Meng H, Tonnesen MG, Marchese MJ, Clark RA, Bahou WF, Gruber BL. Mast cells are potent regulators of endothelial cell adhesion molecule ICAM-1 and VCAM-1 expression. J Cell Physiol. 1995;165:40-53.

8. Gibbs BF, Wierecky J, Welker P, Henz BM, Wolff HH, Grabbe J. Human skin mast cells release preformed and newly generated TNF-alpha and IL-8 but not IL-4, IL-5 or IL-13 following stimulation with anti-IgE and other secretagogues. Exp Dermatol. 2001;10:312-320.

9. Gibbs BF, Arm JP, Gibson K, Lee TH, Pearce FL. Human lung mast cells release small amounts of interleukin-4 and tumour necrosis factor-alpha in response to stimulation by anti-IgE and stem cell factor. Eur $J$ Pharmacol. 1997;327:73-78.

10. Okayama Y, Petit-Frére C, Kassel O, Semper A, Quint D, et al. IgE-dependent expression of mRNA for IL-4 and IL-5 in human lung mast cells. J Immunol. 1995;155:1796-1808.

11. Schroeder JT, Kagey-Sobotka A, MacGlashan DW, Lichtenstein LM. The interaction of cytokines with human basophils and mast cells. Int Arch Allergy Immunol. 1995;107:79-81.

12. Arock M, Merle-Béral H, Dugas B, Ouaaz F, Le Goff L, et al. IL-4 release by human leukemic and activated normal basophils. J Immunol. 1993;151:1441-1447.

13. Brunner T, Heusser CH, Dahinden CA. Human peripheral blood basophils primed by interleukin 3 (IL-3) produce IL-4 in response to immunoglobulin E receptor stimulation. J Exp Med. 1993;177:605-611.

14. MacGlashan DW, White JM, Huang SK, Ono SJ, Schroeder JT, Lichtenstein LM. Secretion of IL-4 from human basophils. The relationship between IL-4 mRNA and protein in resting and stimulated basophils. J Immunol. 1994;152:3006-3016.

15. Gibbs BF, Haas H, Falcone FH, Albrecht C, Vollrath IB, et al. Purified human peripheral blood basophils release interleukin-13 and preformed interleukin-4 following immunological activation. Eur J Immunol. 1996; 26:2493-2498.

16. Ochensberger B, Daepp GC, Rihs S, Dahinden CA. Human blood basophils produce interleukin-13 in response to IgE-receptor-dependent and -independent activation. Blood. 1996;88:3028-3037.

17. Li H, Sim TC, Alam R. IL-13 released by and localized in human basophils. J Immunol. 1996;156:4833-4838.

18. Schroeder JT, MacGlashan DW, Lichtenstein LM. Human basophils: mediator release and cytokine production. Adv Immunol. 2001;77: 93-122.

19. Marone G, Triggiani M, de Paulis A. Mast cells and basophils: friends as well as foes in bronchial asthma? Trends Immunol. 2005;26:25-31.

20. Iikura M, Miyamasu M, Yamaguchi M, Kawasaki H, Matsushima K, et al. Chemokine receptors in human basophils: inducible expression of functional CXCR4. J Leukoc Biol. 2001;70:113-120.

21. Falcone FH, Zillikens D, Gibbs BF. The 21 st century renaissance of the basophil? Current insights into their role in allergic responses and innate immunity. Exp Dermatol. 2006;15:855-864.

22. Nouri-Aria KT, Irani AM, Jacobson MR, O'brien F, Varga EM, et al. Basophil recruitment and IL-4 production during human allergeninduced late asthma. J Allergy Clin Immunol. 2001;108:205-211.

23. Luccioli S, Brody DT, Hasan S, Keane-Myers A, Prussin C, Metcalfe DD. $\operatorname{IgE}(+)$, Kit(-), I-A/I-E(-) myeloid cells are the initial source of Il-4 after antigen challenge in a mouse model of allergic pulmonary inflammation. $J$ Allergy Clin Immunol. 2002;110:117-124.

24. Devouassoux G, Foster B, Scott LM, Metcalfe DD, Prussin C. Frequency and characterization of antigen-specific IL-4 and IL-13-producing basophils and $\mathrm{T}$ cells in peripheral blood of healthy and asthmatic subjects. J Allergy Clin Immunol. 1999;104:811-819.

25. Ocmant A, Michils A, Schandene L, Peignois Y, Goldman M, Stordeur P. IL-4 and IL-13 mRNA realtime PCR quantification on whole blood to assess allergic response. Cytokine. 2005;31:375-381.

26. Ying S, Meng Q, Barata LT, Robinson DS, Durham SR, Kay AB Associations between IL-13 and IL-4 (mRNA and protein), vascular cell adhesion molecule-1 expression, and the infiltration of eosinophils, macrophages, and $\mathrm{T}$ cells in allergen-induced late-phase cutaneous reactions in atopic subjects. $J$ Immunol. 1997;158:5050-5057.

27. Li L, Xia Y, Nguyen A, Lai YH, Feng L, Mosmann TR, Lo D. Effects of Th2 cytokines on chemokine expression in the lung: IL-13 potently induces eotaxin expression by airway epithelial cells. $J$ Immunol. 1999; $162: 2477-2487$

28. Moore PE, Church TL, Chism DD, Panettieri RA, Shore SA. IL-13 and IL-4 cause eotaxin release in human airway smooth muscle cells: a role for ERK. Am J Physiol Lung Cell Mol Physiol. 2002;282:847-853.

29. Haas H, Falcone FH, Holland MJ, et al. Early interleukin-4: its role in the switch towards a Th2 response and IgE-mediated allergy. Int Arch Allergy Immunol. 1999;119:86-94.

30. Lantz CS, Boesiger J, Song CH, Mach N, Kobayashi T, et al. Role for interleukin-3 in mast-cell and basophil development and in immunity to parasites. Nature. 1998;392:90-93.

31. Obata K, Mukai K, Tsujimura Y, Ishiwata K, Kawano Y, et al. Basophils are essential initiators of a novel type of chronic allergic inflammation. Blood. 2007;110:913-920.

32. Sato E, Hirahara K, Wada Y, Yoshitomi T, Azuma T, et al. Chronic inflammation of the skin can be induced in $\operatorname{IgE}$ transgenic mice by means of a single challenge of multivalent antigen. J Allergy Clin Immunol. 2003;111:143-148.

33. Mukai K, Matsuoka K, Taya C, Suzuki H, Yokozeki H, et al. Basophils play a critical role in the development of IgE-mediated chronic allergic inflammation independently of T cells and mast cells. Immunity. 2005;23:191-202.

34. Smurthwaite L, Walker SN, Wilson DR, Birch DS, Merrett TG, Durham SR, Gould HJ. Persistent IgE synthesis in the nasal mucosa of hay fever patients. Eur J Immunol. 2001;31:3422-3431.

35. Gould HJ, Sutton BJ, Beavil AJ, Beavil RL, McCloskey N, et al. The biology of IGE and the basis of allergic disease. Annu Rev Immunol. 2003:21:579-628

36. Yanagihara Y, Kajiwara K, Basaki Y, Ikizawa K, Ebisawa M, et al. 
Cultured basophils but not cultured mast cells induce human IgE synthesis in B cells after immunologic stimulation. Clin Exp Immunol. 1998;111:136-143.

37. Gauchat JF, Henchoz S, Mazzei G, Aubrey J-P, Brunner T, et al. Induction of human IgE synthesis in B cells by mast cells and basophils. Nature. 1993;365:340-343.

38. Noben-Trauth N, Shultz LD, Brombacher F, et al. An interleukin 4 (IL-4)-independent pathway for CD4+ T cell IL-4 production is revealed in IL-4 receptor-deficient mice. Proc Natl Acad Sci U S A. 1997;94:10838-10843.

39. Kaplan MH, Schindler U, Smiley ST, Grusby MJ. Stat6 is required for mediating responses to IL-4 and for development of Th2 cells. Immunity. 1996;4:313-319.

40. Shim JY, Kim BS, Cho SH, Min KU, Hong SJ. Allergen-specific conventional immunotherapy decreases immunoglobulin E-mediated basophil histamine releasability. Clin Exp Allergy. 2003;33:52-57.

41. Sokol CL, Barton GM, Farr AG, Medzhitov R. A mechanism for the initiation of allergen-induced $\mathrm{T}$ helper type 2 responses. Nat Immunol. 2007:9:310-318.

42. Falcone FH, Morroll S, Gibbs BF. Lack of protease activated receptor (PAR) expression in purified human basophils. Inflamm Res. 2005;54(suppl 1):S13-S14.

43. Phillips C, Coward WR, Pritchard DI, Hewitt CR. Basophils express a type 2 cytokine profile on exposure to proteases from helminths and house dust mites. J Leukoc Biol. 2003;73:165-171.

44. Min B, Prout M, Hu-Li J, Zhu J, Jankovic D, et al. Basophils produce IL-4 and accumulate in tissues after infection with a Th2-inducing parasite. J Exp Med. 2004;200:507-517.

45. Voehringer D, Reese TA, Huang X, Shinkai K, Locksley RM. Type 2 immunity is controlled by IL-4/IL-13 expression in hematopoietic non-eosinophil cells of the innate immune system. J Exp Med. 2006; 203:1435-1446.

46. Falcone FH, Haas H, Gibbs BF. The human basophil: a new appreciation of its role in immune responses. Blood. 2000;96:4028-4038.

47. Sin AZ, Roche EM, Togias A, Lichtenstein LM, Schroeder JT. Nerve growth factor or IL-3 induces more IL-13 production from basophils of allergic subjects than from basophils of nonallergic subjects. $J$ Allergy Clin Immunol. 2001;108:387-393.

48. Gibbs BF, Zillikens D, Grabbe J. Nerve growth factor influences IgE-mediated human basophil activation: functional properties and intracellular mechanisms compared with IL-3. Int Immunopharmacol. 2005;5:735-747.

49. Bonini S, Lambiase A, Angelucci F, Magrini L, Manni L, Aloe L. Circulating nerve growth factor levels are increased in humans with allergic diseases and asthma. Proc Natl Acad Sci U S A. 1996;93: 10955-10960.

50. Braun A, Quarcoo D, Schulte-Herbruggen O, Lommatzsch M, Hoyle G, Renz H. Nerve growth factor induces airway hyperresponsiveness in mice. Int Arch Allergy Immunol. 2001;124:205-207.

51. Gaddy JN, Busse WW. Enhanced IgE-dependent basophil histamine release and airway reactivity in asthma. Am Rev Respir Dis. 1986;134: 969-974.

52. Beck LA, Marcotte GV, MacGlashan D, Togias A, Saini S. Omalizumabinduced reductions in mast cell Fcepsilon RI expression and function. J Allergy Clin Immunol. 2004;114:527-530.

53. Noga O, Hanf G, Kunkel G, Kleine-Tebbe J. Basophil histamine release decreases during omalizumab therapy in allergic asthmatics. Int Arch Allergy Immunol. 2007;146:66-70.

54. Kepley CL. Antigen-induced reduction in mast cell and basophil functional responses due to reduced Syk protein levels. Int Arch Allergy Immunol. 2005;138:29-39.

55. Gimborn K, Lessmann E, Kuppig S, Krystal G, Huber M. SHIP down-regulates FcepsilonR1-induced degranulation at supraoptimal IgE or antigen levels. J Immunol. 2005;174:507-516.

56. Vonakis BM, Gibbons S Jr, Sora R, Langdon JM, MacDonald SM. Src homology 2 domain-containing inositol $5^{\prime}$ phosphatase is negatively associated with histamine release to human recombinant histamine-releasing factor in human basophils. J Allergy Clin Immunol. 2001;108:822-831.

57. Gibbs BF, Rathling A, Zillikens D, Huber M, Haas H. Initial Fc epsilon RI-mediated signal strength plays a key role in regulating basophil signaling and deactivation. J Allergy Clin Immunol. 2006;118: 1060-1067.

58. Bachelet I, Munitz A, Moretta A, Moretta L, Levi-Schaffer F. The inhibitory receptor IRp60 (CD300a) is expressed and functional on human mast cells. J Immunol. 2005;175:7989-7995.

59. Shiratori I, Yamaguchi M, Suzukawa M, Yamamoto K, Lanier LL, Saito T, Arase H. Down-regulation of basophil function by human CD200 and human herpesvirus-8 CD200. J Immunol. 2005;175: $4441-4449$.

60. Yokoi H, Choi OH, Hubbard W, Lee HS, Canning BJ, et al. Inhibition of FcepsilonRI-dependent mediator release and calcium flux from human mast cells by sialic acid-binding immunoglobulin-like lectin 8 engagement. J Allergy Clin Immunol. 2008;121:499-505.

61. Kepley CL, Taghavi S, Mackay G, Zhu D, Morel PA, et al. Co-aggregation of FcgammaRII with FcepsilonRI on human mast cells inhibits antigen-induced secretion and involves SHIP-Grb2-Dok complexes. J Biol Chem. 2004;279:35139-35149. 